\title{
Chapter 6 \\ Wood-Based Energy as a Strategy for Climate Change Mitigation in the Arctic-Perspectives on Assessment of Climate Impacts and Resource Efficiency with Life Cycle Assessment
}

\section{Laura Sokka}

\begin{abstract}
Northern countries are committing themselves to large cuts in the greenhouse gas (GHG) emissions within the next decades. For example, the EU has agreed to cut down its GHG emissions by $40 \%$ by 2030. In a similar manner, Norway has announced commitments to reduce its GHG emissions by $40 \%$ by 2030 compared to 1990 . Achievement of these emission reduction targets will mean shifting the balance of energy consumption in the region towards renewable sources such as wind, solar and biomass. There are large forest resources in the Nordic countries. Moreover, as a result of warming climate, the boreal forest line is expected to move northwards, displacing $11-50 \%$ of the tundra by boreal forests within the next 100 years. Increasing the use of bioenergy can provide emission reductions while also simultaneously help to reduce regional reliance on fossil fuels. On the other hand, increased mobilisation of forest biomass for energy decreases the growth of forest carbon sink and may in some cases even turn it into a carbon source.

In the present chapter, the use of forest bioenergy to ensure energy security and climate change mitigation is discussed. In addition, conclusions are drawn on how to simultaneously enhance energy security and resource efficiency, and contribute to emission reduction.
\end{abstract}

L. Sokka $(\bowtie)$

Fulbright Arctic Initiative, Helsinki, Finland

e-mail: Laura.i.sokka@gmail.com

(C) The Author(s) 2017

K. Latola, H. Savela (eds.), The Interconnected Arctic - UArctic Congress 2016,

Springer Polar Sciences, DOI 10.1007/978-3-319-57532-2_6 


\subsection{Introduction and Background}

In order to efficiently limit climate change, drastic changes in our present energy systems are needed. Increased use of forest and other biomass for energy has been identified as one central measure for climate change mitigation (Matthews et al. 2014). Forests also have an important role as carbon sinks in the mitigation of climate change (Pan et al. 2011). Increased mobilization of forest biomass for energy decreases the growth of this sink and may even turn it into a carbon source.

While forests and other bioenergy are considered an important source of energy, there are also many other existing and new uses for biomass. In the Arctic, in addition to being a source of materials and fuels, forests have important roles for example for reindeer herding and recreational use, including berry and mushroom picking. Forests are also a central source of biodiversity, particularly the old-growth forests (Koponen et al. 2015). Therefore decisions on alternative forest use options have to be made under complex and uncertain conditions. This calls for comprehensive assessments.

In this study, the use of forest biomass for energy under these complex conditions is discussed. The problematics related to the climate impacts of the use of slow-rotating forests are presented. In addition, the multiple use of forest biomass and the possibilities to combine the different uses are discussed.

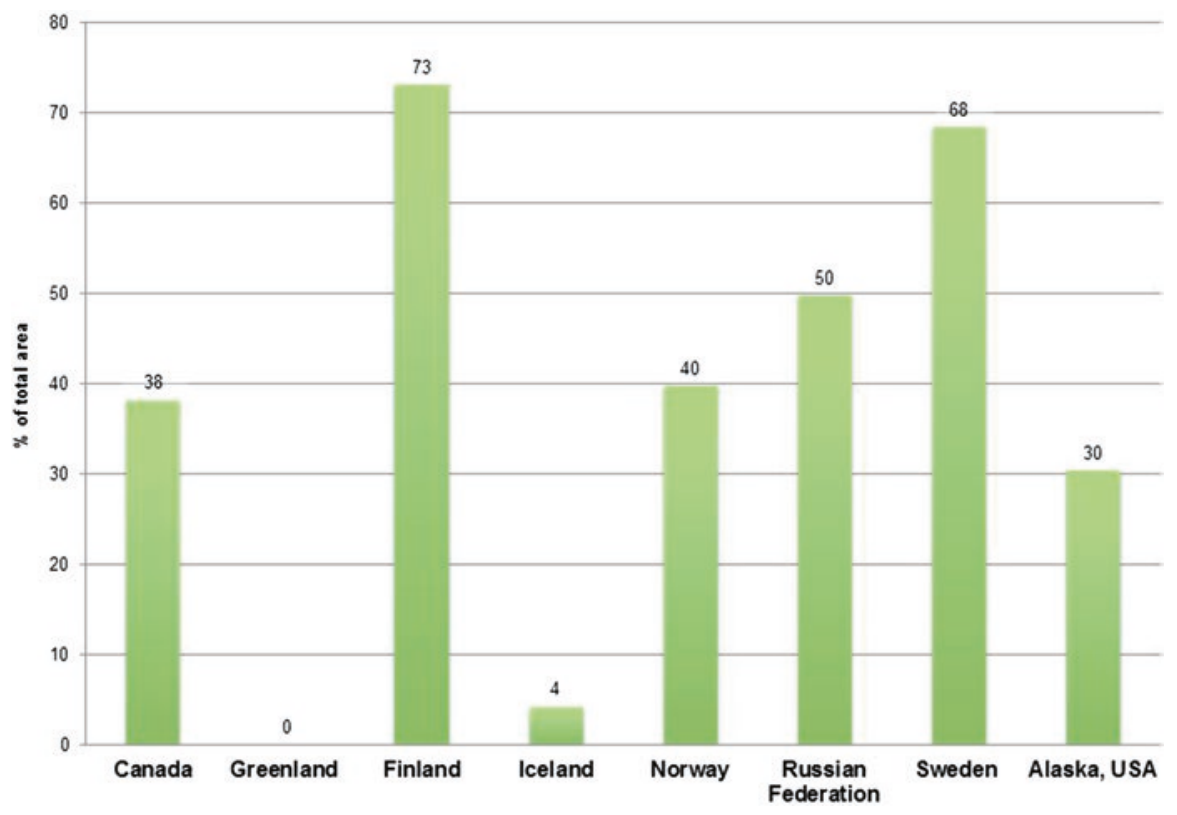

Fig. 6.1 Forest area as percentage of total area in the Arctic countries (FAO 2016) 


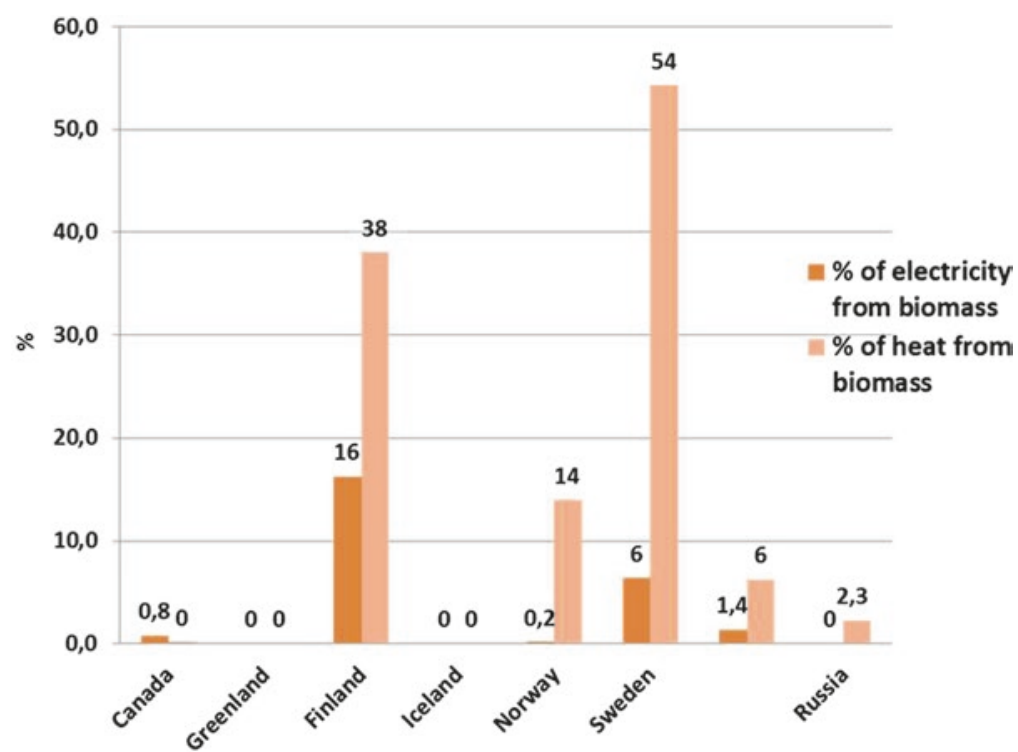

Fig. 6.2 Share of biomass of the total electricity and heat production (IEA 2015a, b)

\subsection{Forests in the Arctic Countries}

Many of the Arctic countries have large forest resources and forests play a substantial economic role in several of them (Fig. 6.1). For example, the USA, Canada, Sweden, Russia and Finland are among the world's largest exporters of pulp, paper and saw mill products (FAO 2015). In Norway, forest industry's role in the national economy is much smaller. Furthermore, in Alaska forest industry is fairly small and wood exports make up only a few percent of the State's exports (Alaska Forest Association 2016).

In some of the Arctic countries, forest biomass also plays an important role in the energy mix (Fig. 6.2). This is particularly true for Finland, Sweden and Norway. On the other hand, in the USA, Canada and Russia, the use of forest biomass ranges from zero to a few percent.

\subsection{Climate Impacts Related to the Use of Forest Biomass for Energy}

During the recent years, several studies have assessed the climate impacts of the use of boreal forests (for review see e.g. Matthews et al. 2014). The idea of the carbon neutrality of the use of forest biomass is based on the notion that in sustainable forestry, the extracted wood will eventually grow back, and re-absorb the carbon that was released (Helin et al. 2013). However, if wood is used for energy or for 


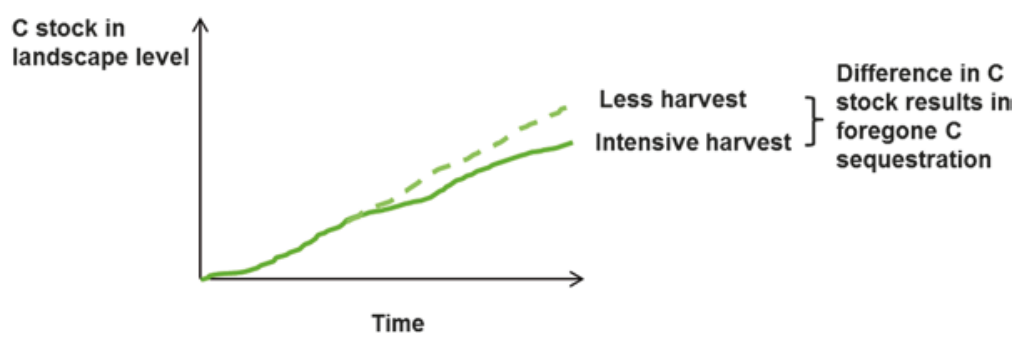

Fig. 6.3 Schematic figure of a difference between intensive and less intensive forest harvest scenarios (Figure adapted from Koponen et al. 2015)

other short-lived products, the carbon contained in it is released into the atmosphere quickly. As boreal forests are slow-growing, it takes from decades to even centuries for it to absorb the released $\mathrm{CO}_{2}$ from the atmosphere. The so-called climate debt from the utilisation of forest biomass for energy, that has been discussed a lot during the past years, stems from the following: when biomass is taken from the forest, an unavoidable reduction in forest carbon stock is caused compared to a situation where biomass is not taken (Pingoud et al. 2015).

To conclude how efficiently biomass harvesting works in climate change mitigation, forest biomass harvesting needs to be studied in relation to a reference situation where less biomass is harvested for energy (see Fig. 6.3). In Fig. 6.3, two scenarios with different levels of extraction of forest biomass have been compared. The amount of carbon stored in the forest increases in both of them over time. Thus, forests form a carbon sink in both scenarios. However, in the case where forest is more intensively harvested, the resulting carbon stock is smaller. This impacts the atmospheric $\mathrm{C}$ balance. What the resulting actual total impact of the wood stemming from either one of these scenarios is, will depend on the use of the biomass, and what is replaced by it.

Life cycle assessment (LCA), which is a tool for quantitatively and systematically evaluating the potential environmental impacts of a product throughout its whole life cycle, has been applied in many studies that assess the climate impacts of wood biomass use (e.g. Holtsmark 2013; Mitchell et al. 2012). As in principle, in LCA all the inflows and outflows of substances, and the impacts of these, in a certain system, are assessed, LCA provides means to identify effective policy options. It also provides the kind of knowledge that reduces the risk of problem shifting. This implies e.g. situations where an improvement in one part of the life cycle leads to weakening in another time or place.

\subsection{Adjusting the Different Uses of Forest Biomass}

The on-going big initiatives for increased forest biomass use in the Finnish Lapland are driven first and foremost by climate change mitigation. However, climate change mitigation and energy industries are not the only users of forest biomass in the Finnish Lapland. 
There are several different users of the forest biomass in the Arctic (e.g. Horstkotte et al. 2016). Even just in the Finnish Lapland, forests are used by forest and energy industry, reindeer herding, source of berries and mushrooms, tourism and even mining operations. Wood and forests are also influenced by policies focused on resource efficiency, energy, biodiversity, reindeer husbandry and tourism, among others.

Some previous research has studied the visions of the different stakeholders on forest biomass use [e.g. Horstkotte et al. 2016; Sténs et al. 2016; Lindahl 2015]. As could be expected, these studies indicate that the different groups have different visions of forest biomass use. However, synergies can also be identified. For example, increased energy use of wood implies increased self-sufficiency in energy use. Forests also have an important role as a source of employment in rural areas. This could mean, for example, rural-based small-scale entrepreneurship, ranging from the development of new wood products, berry and mushroom picking (as both subsistence use and for commercial purposes) and reindeer husbandry to tourism and recreation.

In Finland, there is a long tradition of policies concerning bioenergy production with specific recommendations for energy wood harvesting. Forests are also a key element in the national renewable energy policy, and increased use of bioenergy is also considered a potential way to improve the economic situation in the forest sector. Nevertheless, involvement of the local people in the decision-making through participatory methods and public hearings in e.g. environmental impact assessment is of central importance in order to implement climate change mitigation in the forest management planning (Ogden and Innes 2009). Furthermore, as different uses of forest biomass are often conflicting, management strategies that take into account the multiple values and uses have been found to be the best (Waeber et al. 2013).

Future research in the sustainable use of forest biomass for energy, particularly in the Arctic, should increasingly focus into identifying pathways that are sustainable from multiple perspectives. Understanding the impacts and challenges resulting from climate change need also further consideration.

\section{References}

Alaska Forest Association (2016) Alaska Forest Facts. Available in http://www.akforest.org/facts. htm. Cited on 10th Sept 2016

FAO (2015) Forest product consumption and production. Forest products statistics. http://www. fao.org/forestry/statistics/80938@180723/en/. Cited on 15th Jan 2017

FAO (2016) Faostat. Statistics Division. Food and Agricultural Organization. http://faostat3.fao. org/home/E Cited on 9th Sept 2016

Helin T, Sokka L, Soimakallio S, Pingoud K, Pajula T (2013) Approaches for inclusion of forest carbon cycle in life cycle assessment - a review. GCB Bioenergy 5(5):475-486. doi:10.1111/ gcbb. 12016

Holtsmark B (2013) Boreal forest management and its effect on atmospheric $\mathrm{CO}_{2}$. Ecol Model 248:130-134

Horstkotte T, Lind T, Moen J (2016) Quantifying the implications of different land users' priorities in the management of boreal multiple-use forests. Environ Manag 57:770-783 
IEA (2015a) Energy statistics of OECD countries. 2015 edition. IEA Statistics. International Energy Agency (IEA). Paris

IEA (2015b) Energy statistics of non-OECD countries, 2015 edition. IEA Statistics. International Energy Agency (IEA). Paris.

Koponen K, Sokka L, Salminen O, Sievänen R, Pingoud K, Ilvesniemi H, Routa J, Ikonen T, Koljonen T, Alakangas E, Asikainen A, Sipilä K (2015) Sustainability of forest energy in Northern Europe, VTT technology, 237. VTT, Espoo

Lindahl KB (2015) Chapter 8: Actors' perceptions and strategies: forests and pathways to sustainability. In: Westholm E, Lindahl KB, Kraxner F (eds) The future use of Nordic forests: a global perspective. Springer, Switzerland

Matthews R, Sokka L, Soimakallio S, Mortimer N, Rix J, Schelhaas M, ..., and Randle T (2014) Review of literature on biogenic carbon and life cycle assessment of forest bioenergy. Final Task 1 report (No. ENER/C1/427). The Research Agency of the Forestry Commission

Mitchell SR, Harmon ME, O'Connell KEB (2012) Carbon debt and carbon sequestration parity in forest bioenergy production. GCB Bioenergy 4:818-827

Ogden AE, Innes JL (2009) Adapting to climate change in the southwest Yukon: locally identified research and monitoring needs to support decision making in sustainable forest management. Arctic 62(2):159-174

Pan Y, Birdsey RA, Fang J, Houghton R, Kauppi PE, Kurz WA et al (2011) A large and persistent carbon sink in the world's forests. Science 333(6045):988-993

Pingoud K, Ekholm T, Soimakallio S, Helin T (2015) Carbon balance indicator for forest bioenergy scenarios. GCB Bioenergy 8:171-182. doi:10.1111/gcbb.12253

Sténs A, Bjärstig T, Nordström E-M, Sandström C, Fries C, Johansson J (2016) In the eye of the stakeholder: the challenges of governing social forest values

Waeber PO, Nitschke CR, Le Ferrec A, Harshaw HW, Innes JL (2013) Evaluating alternative forest management strategies for the Champagne and Aishihik Traditional Territory, Southwest Yukon. J Environ Manag 120:148-156

Open Access This chapter is licensed under the terms of the Creative Commons Attribution 4.0 International License (http://creativecommons.org/licenses/by/4.0/), which permits use, sharing, adaptation, distribution and reproduction in any medium or format, as long as you give appropriate credit to the original author(s) and the source, provide a link to the Creative Commons license and indicate if changes were made.

The images or other third party material in this chapter are included in the chapter's Creative Commons license, unless indicated otherwise in a credit line to the material. If material is not included in the chapter's Creative Commons license and your intended use is not permitted by statutory regulation or exceeds the permitted use, you will need to obtain permission directly from the copyright holder.

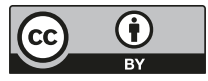

